\title{
DISEMINASI DAN ADOPSI INOVASI TEKNOLOGI PENGOLAHAN HASIL PERIKANAN (Studi Kasus: Kegiatan Iptekmas BBRP2BKP di Yogyakarta)
}

\author{
Christina Yuliaty, Freshty Yulia Arthatiani dan Zahri Nasution \\ Peneliti pada Balai Besar Riset Sosial Ekonomi Kelautan dan Perikanan \\ JI. KS. Tubun Petamburan VI Jakarta 10260 \\ Telp. (021) 53650162, Fax. (021)53650159 \\ Diterima 16 Maret 2011 - Disetujui 11 Mei 2011
}

\begin{abstract}
ABSTRAK
Diseminasi inovasi Teknologi pengolahan hasil perikanan merupakan salah satu kegiatan yang tertuang dalam bentuk Iptekmas di lingkup Badan Penelitian dan Pengembangan (Litbang) Kelautan dan Perikanan. Makalah ini bertujuan memaparkan hasil evaluasi diseminasidan adopsi inovasi teknologi pengolahan tersebut di wilayah Yogayakarta. Kegiatan Iptekmas ini dilakukan oleh Balai Besar Riset pengolahan Produk dan Bioteknologi Kelautan dan Perikanan (BBRP2BKP) pada tahun 2009 dan dievaluasi hasilnya pada tahun 2010. Evaluasi dilakukan dengan menggunakan pendekatan kualitatif terkait dengan kriteria tepat guna bagi suatu inovasi teknologi. Data yang digunakan adalah data primer dan sekunder. Data primer diperoleh melalui wawancara dengan pengolah hasil perikanan yang menerima inovasi teknologi. Teknik analisis data yang digunakan deskripsi kualitatif. Hasil evaluasi menunjukkan bahwa inovasi teknologi pengolahan hasil perikanan yang didiseminasikan pada tahun 2009 telah diadopsi oleh penerima teknologi sesuai dengan kebutuhannya. Teknologi tersebut berupa inovasi peralatan dan metode pengolahan. Inovasi teknologi yang diadopsi dapat secara mudah diadopsi dan secara ekonomi telah menguntungkan serta meningkatkan pendapatan penerima teknologi. Di sisi lain diperlukan adanya difusi inovasi teknologi serupa kepada pengolah lainnya sehingga mereka mendapatkan manfaat yang sama.
\end{abstract}

Kata kunci: Diseminasi, Adopsi Inovasi, Pengolahan Hasil Perikanan

\section{Pendahuluan}

Adams (1988) menyatakan bahwa "an innovation is an idea or object perceived as new by an individual" (dalam Musyafak dan Ibrahim, 2005). Definisi yang lebih lengkap tentang inovasi disampaikan oleh Van Den Ban dan Hawkins (1996) yang menyatakan: "an innovation is an idea, method, or object which is regarded as new by individual, but which is not always the result of recent research" (dalam Musyafak dan Ibrahim, 2005). Dari beberapa definisi tersebut, inovasi mempunyai tiga komponen, yaitu;

(a) ide atau gagasan,

(b) metode atau praktek, dan

(c) produk (barang dan jasa).

Untuk dapat disebut inovasi, ketiga komponen tersebut harus mempunyai sifat "baru". Sifat "baru" tersebut tidak selalu berasal dari hasil penelitian mutakhir. Definisi baru di sini dilihat dari sudut pandang masyarakat calon penerima inovasi tersebut (calon adopter), bukan kapan inovasi tersebut dihasilkan. Artinya hasil penelitian yang sudah lalupun jika baru diintroduksikan kepada calon adopter yang belum mengetahui hasil tersebut maka disebut inovasi. Pada tataran pemahaman yang lebih operasional, inovasi yang dihasilkan oleh suatu lembaga riset dan atau pengkajian dapat berwujud teknologi, ataupun kelembagaan atau suatu kebijakan.

Dalam proses diseminasi suatu inovasi baik berupa suatu teknologi dan ataupun kebijakan diharapkan cepat dapat diterima atau diadopsi oleh penerima atau kelompok sasaran. Oleh karena itu perlu diketahui faktor yang dapat mempengaruhi percepatan adopsi inovasi atau teknologi tersebut. Dalam hal ini, salah satu faktor yang mempengaruhi percepatan adopsi inovasi oleh pengguna adalah sifat dari inovasi itu sendiri. Inovasi yang akan diintroduksikan harus mempunyai banyak kesesuaian (daya adaptif) terhadap kondisi biofisik, sosial, ekonomi, dan budaya yang ada pada calon penerima inovasi atau teknologi tersebut. Untuk itu, inovasi yang ditawarkan ke pengguna harus inovasi yang tepat guna. Sejalan dengan pernyataan tersebut, Musyafak dan Ibrahim (2005) mengemukakan bahwa strategi untuk memilih inovasi yang tepat guna adalah menggunakan beberapa kriteria yaitu;

\section{a). Harus dirasakan sebagai kebutuhan oleh pengguna,}

Agar inovasi diadopsi oleh masyarakat maka inovassi tersebut haruslah benar menjawab kebutuhan mereka, membantu memecahkan masalah/persoalan yang dihadapi calon adopter. Untuk itu harus mengetahui secara benar apa masalah yang dihadapi calon adopter dan cara memecahkan sudah sesuai dengan kondisi mereka sejalan dengan definisi tepat guna.

\section{b). Inovasi harus memberi keuntungan secara konkrit bagi pengguna,}

Masyarakat akan mengadopsi inovasi jikadianggap mampu memberikan keuntungan. Untuk itu perlu adanya perbandingan perhitungan sebelum dan sesuadah inovasi diterapkan. 


\section{c). Inovasi harus mempunyai kompatibilitas/ keselarasan,}

Inovasi juga harus melihat kesesuaian dengan sebelumnya (selaras).

\section{d). Inovasi harus dapat mengatasi faktor-faktor pembatas,}

Inovasi diharapkan dapat memecahkan masalah yang ada di tengah masyarakat atau calon adopter sehingga dapat mencari jalan keluar untuk menghadapi keterbatasan yang ada.

\section{e). Inovasi harus mendayagunakan sumberdaya yang sudah ada,}

Menurut Bunch dalam Musyafak dan Ibrahim, (2005) harus Inovasi menggunakan sumberdaya yang ada karena dnilai murah, mudah diperoleh, sehingga dapat diandalkan. Untuk dapat menghasilkan inovasi yang mendayagunakan sumberdaya yang ada maka terlebih dahulu mengidentifikasi sumber daya lokal yang ada di tengah masyarakat dan mencari teknologi yang memanfaatkan sumberdaya tersebut.

\section{f). Harus terjangkau oleh kemampuan finansial pengguna,}

Kendala terbesar dalam adopsi inovasi adalah besaran biaya yang dibutuhkan dengan kata lain inovasi tersebut masih dapat dijangkau secara finansial oleh calon adopter.Untuk itu perlu mengetahui kemampuan finansial dari calon penerima, lembaga yang dapat menyediakan bantuan modal.

\section{g). Harus sederhana tidak rumit dan mudah dicoba dan diamati.}

Inovasi yang mudah diserap oleh calon adopter adalah inovasi yang sederhana, mudah dicoba. Memiliki pengaruh terhadap percepatan adopsi inovasi. Proses penyebaran (difusi) inovasi dipengaruhi oleh mudah atau tidaknya inovasi tersebut diamati. Semakin mudah diamati makan akan semakin mudah dicontoh maka semakin mudah terjadi penyebaran inovasi.

Penelitian yang merupakan Hasil evaluasi terhadap kegiatan Iptekmas Balai Besar Riset pengolahan Produk dan Bioteknologi Kelautan dan Perikanan (BBRP2BKP) pada tahun 2009 memperlihatkan bahwa Inovasi yang diperkenalkan oleh BBRP2BKP dapat digolongkan kepada kelompok peralatan dan atau metode pengolahan perikanan yang didiseminasikan kepada calon penerimanya yaitu berbagai kelompok masyarakat pengolah hasil perikanan. Dengan adanya proses diseminasi tersebut diharapkan inovasi tersebut diterima oleh calon pengguna dan memberikan manfaat terutama bagi penerima inovasi tersebut. Untuk itu, lebih lanjut diharapkan terjadi perubahan pada calon penerima inovasi tersebut baik terkait dengan cara atau metode pengolahan menggunakan inovasi yang didiseminasikan tersebut. Oleh karena itu, yang perlu dievaluasi adalah sejauhmana inovasi tersebut dapat memberikan manfaat bagi penerima inovasi tersebut.

Tujuh kriteria diatas dapat digunakan untuk melihat apakah inovasi yang diperkenalkan dan diberikan oleh BBRP2BKP sudah bersifat tepat guna bagi penerima bantuan yang diberikan tersbut. Dalam hal ini, semakin banyak kriteria-kriteria tersebut yang dipenuhi oleh suatu inovasi terkait dengan kondisi yang ada pada penerima inovasi, maka semakin besar peluang inovasi tersebut untuk diadopsi dan bermanfaat oleh pengguna Musyafak dan Ibrahim (2005). Sebaliknya, semakin sedikit kriteria-kriteria tersebut yang dipenuhi, maka semakin kecil peluang inovasi tersebut dapat bermanfaat bagi penerima inovasi dalam proses diseminasi yang dilakukan.

\section{Perbaikan Sanitasi Produksi}

Sebagai gambaran salah satu responden (Ibu Ismini) yang merupakan pengolah makanan ringan yang berasal dari ikan lele dan rumput laut. Lokasi usaha berada di Desa Ngendongan, kecamatan Playen, Gunung Kidul. Produk yang dihasilkan antara lain lanting rumput laut dan lele, patilo rumput laut dan lele, kerupuk rumput laut dan lele. Usaha pengolahan ikan dimulai sejak tahun 1994, saat itu produksinya hanya sekitar $10 \mathrm{~kg} /$ produksi. Pengetahuan mengenai pengolahan ini diperoleh dari petugas dinas perikanan.

Bantuan yang diberikan berupa perbaikan sanitasi yaitu berupa perbaikan tempat produksi. Ruangan tempat produksi sudah seluruhnya di keramik dan dalam keadaan cukup bersih. Ruangan tersebut memiliki ukuran P: 8,1 m dan L: 6,3m. Alat Pengaduk/mixer pencampur adonan: dalam kondisi bekas terpakai dan menurut pengakuan responden memang alat tersebut dipakai. Meja lapis stainless steel : dalam keadaan bekas terpakai, tungku pemasakan, kompor gas, blender, dan papan nama. Papan nama dipasang di luar lokasi pengolahan dan mengambil nama 'Maringle' (Makanan Ringan dari ikan lele dan rumput laut).

Pemberian bantuan kepada ibu Ismini berupa perbaikan tempat produksi dan pemngadaan alat pengaduk atau mixer memberikan pengaruh terhadap produksi yang dijalankan. Tabel 1 menjelaskan perubahan aspek produksi yang dirasakan oleh Ibu Ismini selaku responden yang merasakan manfaat dari bantuan tersebut.

Menurut pengakuan responden, ia sangat terbantu dengan alat-alat yang diberikan melalui program Iptekmas ini. Contohnya saja alat pengaduk (mixer pencampur adonan). Sebelumnya responden mencampur menggunakan tangan dan membutuhkan waktu yang lama untuk mendapatkan hasil yang baik. Responden membutuhkan waktu selama 1 jam untuk mencampur adonan, namun setelah ada alat pengaduk, ia hanya membutuhkan waktu selama 10 menit. 
Tabel 1. Perbandingan aspek produksi responden Ibu Ismini sebelum dan sesudah pemberian bantuan

\begin{tabular}{llcc}
\hline No & Komponen & $\begin{array}{c}\text { Sebelum } \\
\text { Menggunakan } \\
\text { Teknologi }\end{array}$ & $\begin{array}{c}\text { Sesudah } \\
\text { Menggunakan } \\
\text { Teknologi }\end{array}$ \\
\hline 1. & $\begin{array}{l}\text { Lama } \\
\text { Pencampuran } \\
\text { Adonan }\end{array}$ & 1 jam & 10 menit \\
2. $\quad \begin{array}{l}\text { Volume } \\
\text { Produksi }\end{array}$ & $25 \mathrm{~kg}$ & $100 \mathrm{~kg}$ \\
3. & $\begin{array}{l}\text { Keuntungan } \\
\text { per produksi }\end{array}$ & $\begin{array}{l}\text { Rp. } \\
100.000\end{array}$ & Rp. 200.000 \\
\hline
\end{tabular}

Sumber: Data Primer 2010

Hal ini juga mempengaruhi jumlah produksi. Awalnya ia hanya mampu berproduksi $25 \mathrm{~kg}$ sekarang bisa mencapai $100 \mathrm{~kg}$. Keuntungan yang diperoleh responden sebelumnya Rp.100.000,00 per kali produksi, namun sekarang bisa mencapai Rp.200.000,00 per kali produksi. Jadi sangat menguntungkan dari segi tenaga, waktu, dan juga ekonomi. Responden menggunakan gas ukuran $12 \mathrm{~kg}$, dengan harga berkisar rp 76.000,00$78.000,00$ yang dapat digunakan selama 8-10 hari.

Mengenai tagihan listrik yang harus dibayarkan akibat penggunaan mixer pengaduk adonan, responden menyatakan bahwa jika dilihat keuntungan yang didapat tidak terlalu jauh berbeda dengan sebelum adanya alat tersebut. Saat ini yang menjadi kesulitan bagi responden adalah faktor cuaca. Produk yang dihasilkan menjadi kurang kering, untuk itu beliau mengutarakan kebutuhannya akan alat pengering yang dapat digunakan saat musim hujan.

\section{Peralatan Pengolahan Makanan Ringan}

Contoh lainnya adalah Ibu Sri Rubiyati, yang merupakan pengolah makanan ringan dari rumput laut dan lele. Produk yang dihasilkan antara lain lanting rumput laut dan lele, stick rumput laut, kerupuk rumput laut,abon tuna,dan pastel kering isi abon tuna. Responden memulai usaha sejak tahun 1995, namun yang dihasilkan hanya lanting biasa. Pengetahuan mengenai lele dan rumput laut dapat menjadi bahan tambahan lanting diperoleh dari petugas Dinas Perikanan, kurang lebih 1 tahun yang lalu. Beliau mendapatkan bantuan berupa meja lapis stainless steel yang berada dalam keadaan dipakai, tungku pemasakan yang juga digunakan, kompor gas, pemotong kerupuk dan blender serta papan nama yang sudah terpasang.

Pemberian bantuan kepada ibu Sri Rubiyati berupa berupa meja lapis stainless steel yang berada dalam keadaan dipakai, tungku pemasakan yang juga digunakan, kompor gas, pemotong kerupuk dan blender serta papan nama yang sudah terpasang memberikan pengaruh terhadap produksi yang dijalankan. Tabel 2 menjelaskan perubahan aspek produksi yang dirasakan oleh Ibu Sri Rubiyati selaku responden yang merasakan manfaat dari bantuan tersebut.

Menurut pengakuan responden, ia merasa sangat dibantu dengan adanya bantuan alat-alat seperti yang disebut di atas. Bantuan yang diberikan membantu proses pengolahannya menjadi lebih cepat, lebih banyak dan lebih higienis. Artinya jauh menguntungkan. Sebagai perbandingan, sebelumnya hanya mampu berproduksi 50-60 kg lanting/minggu, namun sekarang bisa mencapai $1000 \mathrm{~kg}$ dan masih ditambah pastel kering isi abon tuna sebanyak $30 \mathrm{~kg}$. Tenaga kerja yang dibutuhkan masih sama yaitu sekitar 6 orang.

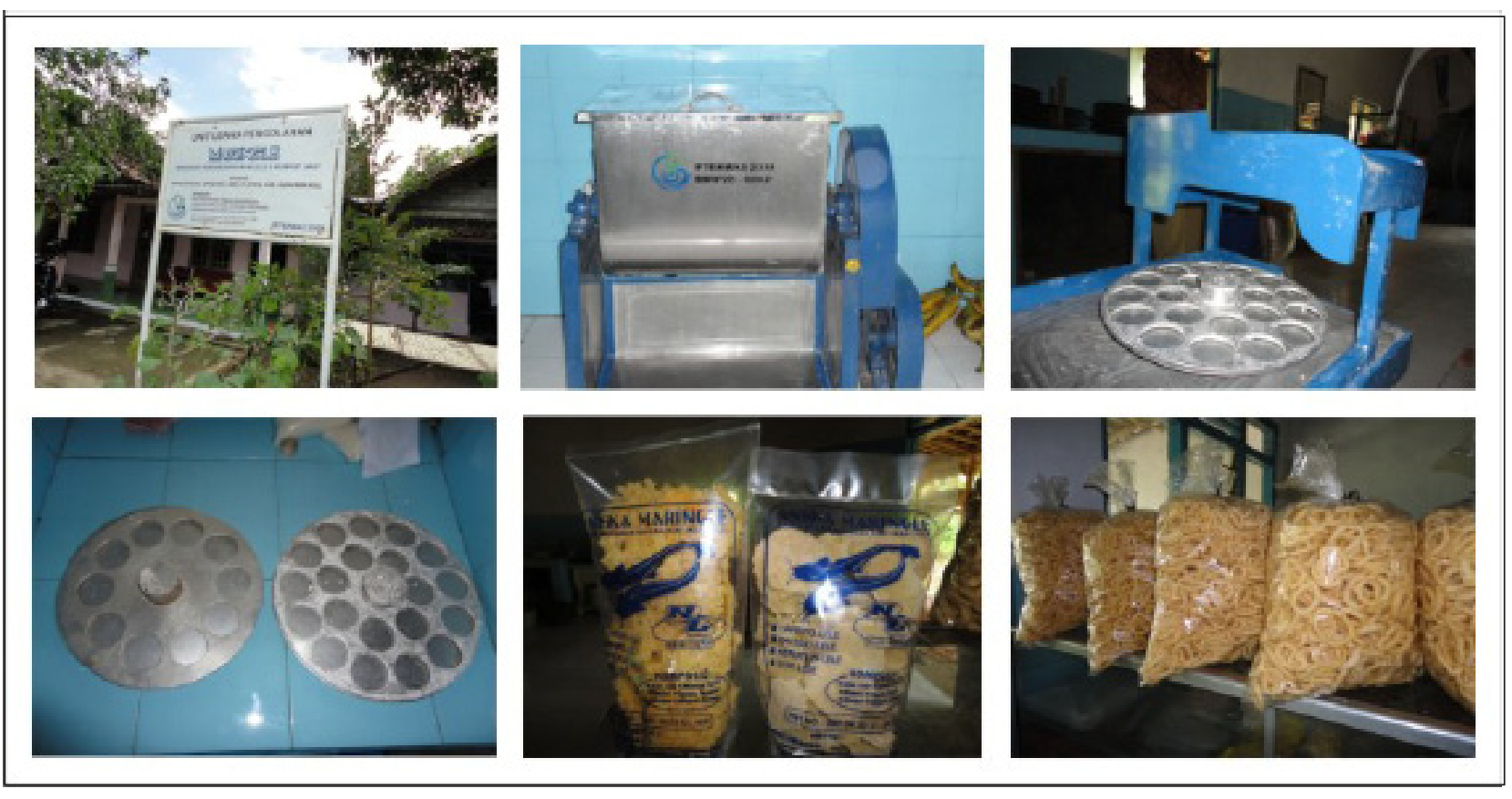


Upah tenaga kerja Rp.17.500,00/ hari (dari jam 08.00-16.00 wib) selebihnya untuk kegiatan memotong dianggap lembur dan dibayar sebesar Rp. 75/potong.

Tabel 2. Perbandingan aspek produksi responden Ibu Sri Rubiyati sebelum dan sesudah pemberian bantuan

\begin{tabular}{llcc}
\hline No & Komponen & $\begin{array}{c}\text { Sebelum } \\
\text { Menggunakan } \\
\text { Teknologi }\end{array}$ & $\begin{array}{c}\text { Sesudah } \\
\text { Menggunakan } \\
\text { Teknologi }\end{array}$ \\
\hline $1 . \quad$ & $\begin{array}{l}\text { Volume } \\
\text { Produksi } \\
\text { Lanting }\end{array}$ & $50-60 \mathrm{~kg}$ & $1.000 \mathrm{~kg}$ \\
& & \\
\hline
\end{tabular}

Sumber: Data Primer 2010

Informasi beliau, meskipun sudah mendapat bantuan kompor gas, tungku yang menggunakan kayu tetap beliau dipergunakan dikarenakan jumlah produksi yang sangat besar. Keuntungan yang diperoleh adalah Rp. 400.000/ton. Responden menggunakan Gas berukuran $12 \mathrm{~kg}$ yang dapat digunakan selama 3-4 hari. Harga pasaran gas $12 \mathrm{~kg}$ berkisar antara Rp. 76.000,00-78.000,00.- Sama dengan ibu Ismini, beliau mengalami kesulitan jika musim penghujan dimana produknya membutuhkan sinar matahari. Menurut pengakuan beliau, jika dimungkinkan ada bantuan alat yang dapat membantu mengeringkan produksi saat musim hujan. Selain itu melihat produksi yang besar, beliau juga membutuhkan mixer pencampur adonan. Ditambah lagi, berdasarkan hasil pengamatan di lapangan, alat pengepress unuk pembuatan abon tuna yang selama ini digunakan sangat tidak higienis.

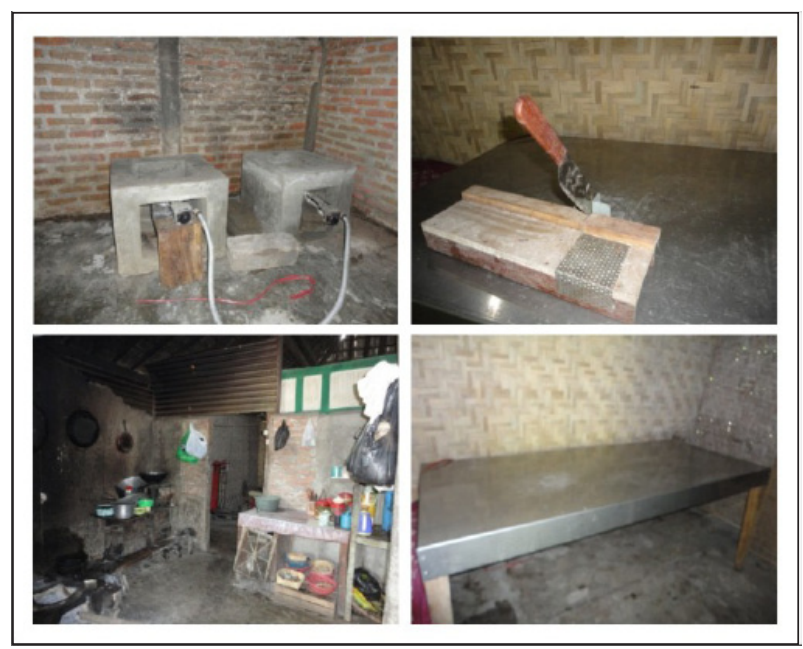

\section{Peralatan Pengolahan Keripik Belut}

Evaluasi selanjutnya dilaksanakan terhadap usaha ibu Ponirah selaku pengolah belut menjadi keripik yang juga mendapat bantuan. Usaha ini berlokasi di Sidoagung, Godean, Sleman. Pada tahun yang lalu, ia mendapat bantuan teknologi berupa alat penggorengan, sealer, rak penirisan, rak penyimpanan, gayung minyak yang terbuat dari stainless steel dan papan nama. Berdasarkan hasil pengamatan tim iptekmas, kesemua alat tersebut telah beliau pergunakan dalam kegiatan produksinya. Alat yang diberikan sudah sesuai dengan kebutuhan ibu ponirah dalam usahanya. Menurutnya hasil yang beliau dapatkan sekarang jauh lebih banyak dan menguntungkan terutama dalam hal waktu kerja. Dengan alat yang diberikan pekerjaan menjadi lebih cepat selesai. Bantuan yang diberikan juga memiliki keselarasan dengan cara yang sebelumnya. Contoh wajan yang diberikan selaras engan yang sebelumnya namun ukurannya lebih besar sehingga mampu menampung lebih banyak belut yang akan diolah. Contoh lainnya adalah rak peniris, sebelumnya hasil olahan ditiriskan dengan alat seadanya, akibatnya hasil olahan masih banyak mengandung minyak. Namun dengan rak peniris, hasilnya jauh lebih bersih dan mampu menampung banyak hasil olahan yang akan ditiriskan.

Peralatan yang diberikan dapat mengatasi faktor-faktor pembatas yang ada sebelumnya. Antara lain waktu menjadi lebih cepat, selain itu juga mampu mengatasi masalah kebersihan hasil olahan karena tidak lagi banyak mengandung minyak. Peralatan yang diberikan juga mampu mendayagunakan sumberdaya yang ada. Sebagai contoh bantuan sealer yang mempermudah dalam mengemas hasil sehingga waktu mengemas lebih cepat dan menambah daya simpan produk. Bliau menambahkan, semua peralatan yang diberikan dapat dikatakan sederhana, tidak rumit dan mudah dipergunakan. Beliau mengungkapkan bahwa, alat yang sudah diberikan selain sangat membantu juga dapat terjangkau secara financial. Hal ini diperlukan jika suatu saat beliau harus membeli alat-alat tersebut dengan uang sendiri.

\section{Peralatan Pengolahan Bandeng Presto}

Di lain pihak, Bapak Tugiman merupakan salah seorang pengolah bandeng presto dari Code, Trirenggono, Bantul. Beliau mendapat bantuan berupa perbaikan sanitasi ruang pengolahan, alat pengolah bandeng presto, tungku pemasak, cerobong asap dan papan nama. Menurut pengakuan beliau, peralatan yang diberikan sudah sesuai dengan kebutuhannya dalam produksi bandeng presto.

Keuntungan yang beliau dapatkan juga jauh meningkat dengan adanya bantuan alat tersebut. Sebelumnya hanya mampu memproduksi bandeng presto $50 \mathrm{~kg} /$ hari, sekarang $100 \mathrm{~kg} /$ hari. Dulu hanya mampu memenuhi permintaan dari 2 orang pelanggan sekarang sudah 7 orang pelanggan. Laba bersih yang didapatnya dulu hanya Rp. 100.000/hari sementara sekarang Rp. 200.000/hari. Alat yang diberikan membantu Bapak Tugiman bekerja dengan lebih praktis, mudah dan ringan. Bandeng presto yang dihasilkan menjadi lebih bersih dan beliau juga menambahkan, bandeng tersebut tidak lagi bau tanah, durinyapun jauh lebih lunak. 
Tabel 3. Perbandingan aspek produksi responden Bapak Tugiman sebelum dan sesudah pemberian bantuan

\begin{tabular}{|c|c|c|c|}
\hline No & Komponen & $\begin{array}{c}\text { Sebelum } \\
\text { Menggunakan } \\
\text { Teknologi }\end{array}$ & $\begin{array}{c}\text { Ssudah } \\
\text { Menggunakan } \\
\text { Teknologi }\end{array}$ \\
\hline 1. & $\begin{array}{l}\text { Lama } \\
\text { pengolahan }\end{array}$ & 2 jam & 1 jam \\
\hline 2. & $\begin{array}{l}\text { Volume } \\
\text { Produksi } \\
\text { Bandeng } \\
\text { Presto }\end{array}$ & $50 \mathrm{~kg} / \mathrm{hari}$ & $100 \mathrm{~kg} /$ hari \\
\hline 3. & $\begin{array}{l}\text { Jumlah } \\
\text { Pelanggan }\end{array}$ & 2 orang & 7 orang \\
\hline 4. & Bahan Bakar & Rp. $40.000 /$ hari & Rp. $25.000 /$ hari \\
\hline 5. & Laba Bersih & Rp. $100.000 /$ hari & Rp. $200.000 /$ hari \\
\hline
\end{tabular}

Sumber: Data Primer 2010

Tungku pemasak yang diberikan sangat mudah pengoperasiaannya, bahkan jauh lebih mudah dan tentunya hemat bahan bakar. Sebagai perbandingan, alat pengolah yang sebelumnya,terbuat dari besi, membutuhkan waktu selama 2 jam untuk satu kali proses produksi sementara yang diberikan melalui IPTEKMAS terbuat dari stainless steel hanya membutuhkan waktu 1 jam. Dengan demikian alat yang diberikan mampu mendayagunakan sumberdaya yang ada baik dalam hal waktu, tenaga serta dana.

Bapak Tugiman juga menyatakan bahwa alat yang diberikan cukup terjangkau secara finansial. Sebagai contoh, dengan tungku masak yang baru, beliau hanya membutuhkan biaya untuk bahan bakar, dalam hal ini kayu bakar, senilai Rp.25.000 yang sebelumnya mencapai Rp.40.000,--. Kayu bakar dipilih sebagai bahan bakar dengan alasan dapat menekan biaya produksi sehingga harga hasil olahan tidak terlalu mahal. Saat ini Bapak Tugiman memiliki 3 orang karyawan yang membantunya dalam menjalankan usaha bandeng presto ini.

Berdasarkan hasil wawancara dengan keempat responden tersebut, inovasi yang diberikan sudah memenuhi ketujuh syarat inovasi tepat guna di atas.

\section{Kesimpulan}

Kegiatan yang dilakukan merupakan kegiatan diseminasi teknologi hasil-hasil penelitian yang dihasilkan oleh lembaga BBRP2BKP yang sudah dilakukan melalui kegiatan IPTEKMAS tahun yang lalu. Inovasi yang diperkenalkan oleh BBRP2BKP dapat digolongkan kepada kelompok peralatan dan atau metode pengolahan perikanan yang didiseminasikan kepada calon penerimanya yaitu berbagai kelompok masyarakat pengolah hasil perikanan.

Tujuannya untuk melihat apakah Inovasi yang diperkenalkan dan diberikan oleh BBRP2BKP sudah bersifat tepat guna bagi penerima bantuan dalam hal ini pengolah hasil perikanan di beberapa kabupaten di
Daerah Istimewa Yogyakarta (DIY).

Dari hasil yang ditemukan di lapangan, inovasi yang diberikan sudah mampu mengatasi masalah yang sebelumnya dihadapi pengolah. Masalah tersebut sebagian besar akibat kendala peralatan. Inovasi yang dideseminasikan oleh BBRP2BKP telah merubah cara ataupun metode pengolahan responden penerima bantuan sehingga mereka mampu meningkatkan produksi, meningkatkan keuntungan sehingga meningkatkan pendapatan mereka.

\section{Daftar Pustaka}

Adams, M.E. 1988. Agricultural Extention in Developing Countries. First Edition. Longman Singapore Publisher Pte Ltd. Singapore

Musyafak, A dan Tatang M. Ibrahim, 2005. Strategi Percepatan Adopsi Dan Difusi Inovasi Pertanian Mendukung Prima Tani, Analisis Kebijakan Pertanian. Volume 3 No. 1, Maret 2005 : 20-37. Pusat Analisis Kebijakan dan Sosial Ekonomi Pertanian. Badan Litbang Pertanian. Departemen Pertanian. Jakarta.

Roger, E.M. dan F. F. Shoemaker. 1987. Memasyarakatkan Ide-Ide Baru. Disarikan Oleh Abdillah Hanafi dari Communication of Innovation. Cetakan KeIV. Usaha Nasional. Surabaya.

Rogers, Everett M. 1986. Communication Technology: The New Media in Society. The Free Press. A Division of Macmillan, Inc. New York. Collier Macmillan Publishers. London.

Rolling, N. G., J. Ascroft. And F. W. Chege. 1985. Difusi Inovasi dan Masalah Kemerataan Dalam Pembangunan di Pedesaan. Dalam E. M. Rogers (Ed). Komunikasi dan Pembangunan: Persfektif Kritis. Hal. 70-89. LP3ES. Jakarta.

Bunch, Roland, 2001. Dua Tongkol Jagung: pedoman pengembangan pertanian berpangkal pada rakyat. Edisi kedua. Yayasan Obor Indonesia. Jakarta dalam Musyafak, A dan Tatang M. Ibrahim, 2005. Strategi Percepatan Adopsi Dan Difusi Inovasi Pertanian Mendukung Prima Tani, Analisis Kebijakan Pertanian 3(1), Maret 2005 : 20-37. Pusat Analisis Kebijakan dan Sosial Ekonomi Pertanian. Badan Litbang Pertanian. Departemen Pertanian. Jakarta.

Soekartawi. 1998. Prinsip Dasar : Komunikasi Pertanian. UI Press. Jakarta dalam Musyafak, A dan Tatang M. Ibrahim, 2005. Strategi Percepatan Adopsi Dan Difusi Inovasi Pertanian Mendukung Prima Tani, Analisis Kebijakan Pertanian 3(1) Maret 2005 : 20-37. Pusat Analisis Kebijakan dan Sosial Ekonomi Pertanian. Badan Litbang Pertanian. Departemen Pertanian. Jakarta.

van den Ban AW, Hawkins HS. 1996. Agricultural Extension. Second Edition. New York: John Wiley \& Son, Inc. 